Journal of Humanities and Social Sciences Studies (JHSSS)

ISSN: 2663-7197

DOI: $10.32996 /$ jhsss

Journal Homepage: www.al-kindipublisher.com/index.php/jhsss

\title{
Formula in Tuja'i Molo'opu Custom Speech Procession of Leaders Acceptance in Gorontalo Community
}

\author{
Rachmi Laya 8 (D) \\ Department of English Education, Faculty of Letters and Culture, Universitas Negeri Gorontalo \\ $\triangle$ Corresponding Author: Rachmi Laya, E-mail: rachmilaya777@gmail.com
}

\section{ARTICLE INFORMATION}

Received: May 08, 2021

Accepted: June 14, 2021

Volume: 3

Issue: 6

DOI: 10.32996/jhsss.2021.3.6.1

\section{KEYWORDS}

Formula, Gorontalo oral literature, leader acceptance ceremony

\section{ABSTRACT}

One of the oral literature which is still used in Gorontalo custom event is Tuja'i Molo'opu. Oral literature is uttered at the ceremonial officials' reception in Gorontalo. As other traditions are changing, Tuja'i Molo'opu also along with the changes of the society. Therefore, it needs to be held as the foundation for the preservation of the study of oral literature of Tuja'i Molo'opu. Thus, the Tuja'i Molo'opu ceremony does not complement the Molo'opu ceremony but contains moral messages, which as ancestors, messages to the man who will lead in Gorontalo. The theory used in this research is the theory of orality Albert Bates Lord and Ruth Finnegan. To apply this theory used two approaches, namely, structural and Ethnographic approaches. The structural approach is used to examine the formula composition of the tuja'l Molo'opu text as oral poetry. While the ethnographic approach is used to explore data on leadership the cultural aspects in the Gorontalo community. The results of this research show that formula tuja'i Molo'opu has the formula (1) repetition of a sentence, (2) repetition of the word group/phrase, (3) formula of word repetition, (4) formula of suffix, (5) formula of varied repetition, (6) parallelism.

\section{Introduction}

Tuja'i molo'opu is one of the traditional ceremonies of the people of Gorontalo that until now grow and develop in the supporting community. Like other oral traditions, every staging of tuja'i molo'opu in Gorontalo society results from an already existing modification. There is no new staging because the lyrics and texts are repeated, but the audience is different. In view of the staging of the oral tradition, Lord (1981: 31) says that every oral tradition performance is an authentic performance. Lord's opinion can be found in tuja'i molo'opu, because each staging tuja'i molo'opu has uniqueness. This uniqueness is due to each staging tuja'i molo'opu influenced by the context that supports it.

Different contexts will affect the formula tuja'i molo'opu. Based on experience, the singer's knowledge, the singer's intimacy with the audience, and the staging situation will affect the formula tuja'i molo'opu. A professional singer will try to find out the background of the audience. Then from the knowledge of the singer, the background of the audience will affect the tuja'i molo'opu formula system in the play.

\section{Methodology}

The theory used in this research is the theory of orality Lord (1976) and Finnegan (1979). To apply this theory used two approaches, namely, structural and Ethnographic approaches. The structural approach is used to examine the formula composition of the tuja'i molo'opu text as oral poetry. At the same time, an ethnographic approach is used to explore data on leadership the cultural aspects in the Gorontalo community.

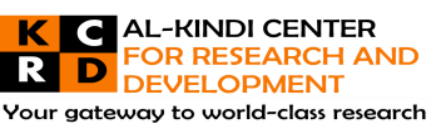

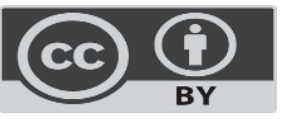

Published by Al-Kindi Center for Research and Development. Copyright (c) the author(s). This open access article is distributed under a Creative Commons Attribution (CC-BY) 4.0 license 


\section{Results and Discussion}

\subsection{The formula in 'Tuja'i Molo'opu'}

Foley states that the formula is the result of a formulaic system (Tuloli, 1991: 143). Further, Foley explained that a formulaic system is a group of arrays that follow the same rhythm and syntactic patterns and have at least one common semantic element. The formula can not be explained by formulaic expression.

According to Lord (1981, p. 30), formulaic expression is an array or a part of arrays arranged on the basis of formulas pattern. Thus, according to Lord (1960: 101, 1976: 4, 1981: 30), the formula is "a group of words which is regularly employed under the same metrical conditions to express a given essential idea".

From the definition, it can be understood that a formula can be words, phrases, clauses, or arrays and appear many times in the story. In addition, there are formulaic expressions that can be utilized, namely word groups based on skeleton or pattern formula (Lord, 1976: 4). According to Ong (1982: 35), the use of formulaic expression can help the formation of rhythmic discourse so that it becomes one of the tools to recall easily, quickly, and precisely and become a fixed expression that can survive orally.

Another important thing that Lord expressed was the absence of memorization by the speaker of oral tradition. The words and lines in the composition of the oral story are composed or created by the narrator using the formula pattern. Speakers of the oral tradition have the freedom to choose and place formulas on the composition of the story at the time of the performance. The technique of the formula was developed to serve himself as an expert or artist (Lord, 1976: 54). The narrator tries to remember the phrases he or she heard from other narrators and who have been used many times in telling a story. They use memories (remembering) as we unconsciously use expressions in ordinary conversation, rather than memorization (Lord, 1976: 55-56). The two ways in which the narrator makes the repetition is to recall and recreate it through the analogous repetition of existing words, phrases, clauses, and arrays. As Lord (1976: 25) says "word means an utterance". By arranging rows based on pattern formulas, there is a process of replacing, combining, modeling, and adding new words or phrases to the formula according to need. Further, Lord (1976: 34) states that every traditional poet presents his story by recreating spontaneously and using a number of available and ready-to-use language elements (words, compounds, phrases). The supply of such formulas is called stock-in-trade.

With reference to the concept, tuja'i molo'opu, a sacred text that became the object of study of this study, including oral poetry that only has the orality aspect limited in the technical sense. Nevertheless, this oral poetry has a form or pattern that is dominant enough to be worthy to study the formula.

The following analysis discusses the features of tuja'i as an oral poem. A common feature of oral poetry is the presence of formulas and formulas. According to Lord (1981: 47), no oral poetry is not formulaic. Discussion of the features of tuja'i trivialism is limited only to prominent elements of prominence, i.e., syntax, parallelism, and repetition patterns.

Beginning from the idea of the formula, the tuja'i molo'opu has a repetition and parallelism system or formula based on (1) array, (2) word group, and (3) word, and (4) suffix through the repetition and parallelism system that later facilitate the tuja'l representative or utolia as well as his performances in the ceremony reception of new officials in Gorontalo government. They can speak tuja'i from one stanza to the next verse without taking too long to think about it, but it will flow away. They perform the text composition of tuja'i through line repetitions by using schematic as sequences that form the tuja'i molo'opu text path.

Besides that, tuja'i molo'opu also has a system of parallelism that allows the singers to compose or compose tuja'i molo'opu when staging in a traditional ceremony of leader acceptance of government because parallelism is two or more parts of the whole sentence of the same form so as to give the pattern certain. In tuja'i molo'opu, parallelism can be seen as a pattern or formula used by all tuja'i molo'opu speakers to compose tuja'i molo'opu. Various kinds of parallelism in tuja'i molo'opu is a rhetorical device with aesthetic value and space that contains sequences of content, direction, and advice in tuja'i molo'opu.

Thus, it can be said that only by understanding the repetition system and parallelism, a singer or even an audience can be directly involved in the staging process of tuja'i molo'opu. By understanding the patterns of repetition and parallelism that exist in the tuja'i molo'opu. So someone will get even greater in having the opportunity to participate in a play.

\subsubsection{Lines formula}

The formula of the sentence is a formula in the form of repetition of the lines. The forms of the formula are used to express one essential idea, meaning the form of formula in tuja'i is used to assert the existence of a central idea. The idea is convenient with the meaning or meaning of the formula form. In tuja' $i$ there is a line consisting of one word and there are four words. The words in this tuja'i also come with the addition of prefixes, suffixes, and reduplications as well. Reduplication in this tuja'i, has a repetition of the same line pattern in some places. To discuss this formula, it will be described in the categories of formulas in tuja'i in this study consisting of 1) repetition of lines, 2) repetition varies, and 3) parallelism. 
Table 1. Full repeat lines formula

\begin{tabular}{|c|c|c|}
\hline Lines & Gorontalo Version & Translation \\
\hline (1) & Wombu pulu hunggia & Grandson of a noble country \\
\hline (170) & 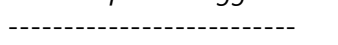 & Grandson of a noble country \\
\hline (201) & Tambuluwa wundluwolo & welcomed and upheld \\
\hline (9) & ------------------------ & welcomed and upheld \\
\hline (78) & Timihulo lumuneo'lo & stand up and move up \\
\hline (11) & 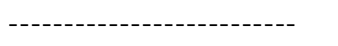 & stand up and move up \\
\hline$(57)$ & Pati hulawa lo hulu & brave son \\
\hline (34) & 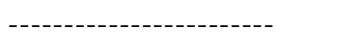 & brave son \\
\hline (88) & Taa pobadari too rasulu & proclaimer sunnah al-rasul \\
\hline (144) & ----------------------------- & proclaimer sunnah al-rasul \\
\hline (145) & Olayidu umuru & Wish you long life \\
\hline (38) & 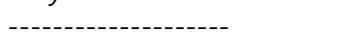 & Wish you long life \\
\hline$(40)$ & Tambuluwa too madala & is celebrated with the country's customs \\
\hline (149) & 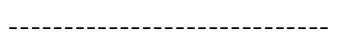 & is celebrated with the country's customs \\
\hline (51) & Tambuluwa tadidiya & is greeted with the greatness of custom \\
\hline (142) & 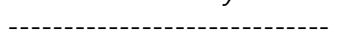 & is greeted with the greatness of custom \\
\hline (159) & 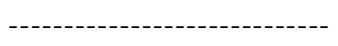 & is greeted with the greatness of custom \\
\hline$(203)$ & 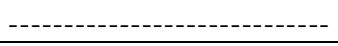 & is greeted with the greatness of custom \\
\hline
\end{tabular}

The quote in the table above shows the formula equation in each tuja'i for example, there are 12 recurring rows. In the pattern of sentence formula in the wombu puluh puluh hunggia 'grandson of a noble country' repeated 3 times, namely: in arrays 1 , 170 and 201. This reveals the traditional leaders are very respectful of leaders. In tambuluwa wunduwolo's row, 'rededicated with greatness' is repeated 2 times in arrays 9 and 55. This line emphasizes respect for leaders. The next line is wawu maa toduwolo 'and is now welcome' repeated 2 times in lines 10 and 78 . This line is to honor and invite. The line timihu lumune'olo 'Please stand and go' repeated 2 times that is on lines 11 and 57. This sentence directs the leader to move. Then the phrase Pati hulawa lo wulu 'grandson noble true' is repeated 2 times ie in the 34 and 143 arrays. This line emphasizes praise to the leader. The next line of wombu payu bulayi 'grandson of aristocracy' repeats twice in lines 88 and 100. This line also emphasizes respect and praise for the leader. Furthermore, the phrase taa pobadari to rasulu 'that continue sunnah al-rasul' repeated as much as 2 times, namely in lines 36 and 145. This line implies the new leader is required to continue the leadership of the Prophet Muhammad. On the line of yilodu'a lo sukuru 'pray and give thanks' is repeated 2 times on lines 38 and 147. This line implies as a religious person, leader, and society should be grateful and pray.

Then, the phrase olayidu umuru 'may long life' repeated as much as 2 times, namely in the array 39 and 148 . This line is the hope of the community for leaders given a long life. Furthermore, in the lumune'o tumundulu line 'increased in every way' repeats twice, in lines 40 and 149. This array is also hope and prayer to the leader. The next line Tombuluwa too madala ' is celebrated with the country's customs' repeated as much as 2 times, namely on lines 51 and 142. This line also expresses respect for the leader. As well as the Tombuluwa tadidiya line 'is greeted with the greatness of custom' repeated 3 times, namely in the arrays 5 , 159, and 203. This line also a report and praise to the leader.

\subsubsection{Various repetition formulas}

This repeatable pattern of variations consists of four parts, namely repetition at the beginning of the first word, being the final word on the second word, usually, this line has only two words. The essential idea of the repetition formula varies like this is to give affirm.

$$
\text { Lo uwito lo utiya That one and this one }
$$

(156) Eya, teeto-teya, teya-teeto God, here and there, herein in order to build respect for the leader.

The next pattern of repeats is that the initial word repetition in the first line is repeated on the third and fifth rows. Similarly, the beginning of the second line is repeated at the beginning of the fourth and sixth lines. Although this one stanza consists of four lines, there are five lines.

Dahayi umayango

Ode botu to payango

Dahayi lumodu'o

To baleyango bitu'o
Be careful not to be careless

$$
\begin{aligned}
& \text { Like a rock in its bedding } \\
& \text { Be careful not to drown }
\end{aligned}
$$

On the kris wave 
The pattern of repeating varied lines such as the above quotation is generally a prohibition and is contained in the elements of advice in each tuja'i variant, i.e. in the lines $(61,63,66)$ and $(62,64$,$) . The three lines contain the word Aadati (custom), diila (not)$ and umalo (already agreed). The word umalo 'has been agreed upon' is in line 67. These three words have the same essence, so he forms a formula with a varied repetition pattern.

\subsection{Formula parallelism}

Parallelism is a style of language formed on the basis of repetition and seeks to achieve parallels in the use of two words or phrases that occupy the same function in the grammatical form (Keraf 1996: 126). In this selected tuja'i, parallelism is quite prominent in these three tuja'i(s). In many instances, the style of parallelism becomes a ready-made formula. Based on this understanding, the parallel form in tuja'i can be divided into three types, namely: a). Parallelism in the row of two lines, and b) parallelism varies.

\subsubsection{Parallelism in the row of two lines}

\section{Adati lo hunggia Provisions of local customs}

Dila hikati-katiya Not with the dosage

Observe the customary members of the Customs

Dila hilabo-labota Not discriminated

$\begin{array}{lc}\begin{array}{l}\text { Adati tomilito } \\ \text { Umalo buli-bulito }\end{array} & \text { Our ancestors } \\ \text { Lengge polayi'opo } & \text { Worship and move on } \\ \text { Lengge poluwalopo } & \text { Seems to exit } \\ \text { Lo uwito lo utiya } & \text { With it and with this } \\ \text { Lo utiya lo uwito } & \text { With this and with it } \\ \text { Pati hulawa asala } & \text { Son of noble generations }\end{array}$

Didi lo upstream aradha Coming from the center of the country

Pati hulawa lo wulu Son of noble generations

Didi lo'u londlo upstream Coming from a high place

Dahayi umayango Be careful not to be careless

Ode botu to payango Like rock in its bed

Dahayi u lumodu'o Be careful not to be affected

To baleyango bitu'o On carving of kris

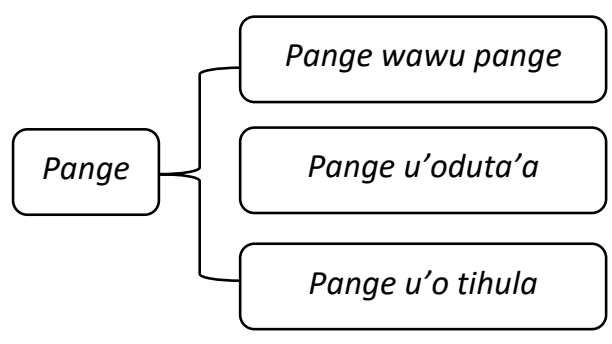

Be empty and be empty

Be empty to stirrup

Be empty for standing place

\begin{tabular}{|l|}
\hline Like a portable luggage \\
\hline Like a filled bamboo \\
\hline
\end{tabular}

\begin{tabular}{|l|}
\hline Like a washed cotton \\
\hline Like pure gold \\
\hline
\end{tabular}

Figure 1. Parallelism in the row of two lines 


\subsubsection{Parallelism Varies}

Lengge ahi motiyale

Yilengge ilo alopo

Lumengge lumuwalopo

Wawu polengge lomayi

Polengge lomayi odiya
Go on

Would be happy to quit

Towards a customary hearing

And please move on

Go for a ride

Variations on the stanza above with the word lengge 'go on'. In the second line yilengge ilo alopo "would be happy to quit" and in the next line lumengge lumuwalopo "towards a customary hearing". From these three lines, in terms of tenses, the first and third lines are the time of the present tense and in the second, fourth, and fifth line, the time of the future tense.

Wombu luwalo lomayi Grandson is welcome out

Luwalayi to ladiya

Get out of the palace

Wombu tuwoto lomayi

Tuwotayi to dutula

Wombu tupalo lomayi

Tupalayi to dutula

\section{Grandson are welcome to enter \\ Enter through this path \\ Grandson are welcome to enter}

Enter through this path

The syntactic parallelism formulas that form the framework of the schematic compositions lie in the elements of praise, direction, and counsel in the tuja'i molo'opu. These lines are, in fact, formulas in a syntactic parallelism pattern, the pattern of parallel sentences.

\subsection{Formula 'Tuja'i Molo'opu' based on word group repetition}

In his explanation of the formula, Lord said that one of the repetitions in the Yugoslavia people's song was the repetition of word groups in the singing. However, the model of this formula can also be found in the tradition of the tuja'i Molo'opu. It is because in addition to using the formula with the pattern of repetition of words or syllables as mentioned above, the tradition tuja'i Molo'opu also has a formula based on group repetition words. The formula with this model is found in the repetition of word groups present at each end of the first line and repeated on the second line of each stanza.

The first-word repetition model on the first line is repeated on the first word of the second, third, and even fourth lines. This model of repetition is similar to the model of parallelism. The number of lines in the stanza is not fixed. Therefore open the opportunity tuja'i speaker to improvise or add to the existing temple-for example, repetition of the initial word on the first line, as below.

Table 2. Word group repetition

\begin{tabular}{cll}
\hline Lines & Gorontalo Version & Translation \\
\hline 1 & Wombu pulu lohunggia & Grandson nobility of the country \\
3 & Lo'u limo lohunggia & Which occupies the five countries \\
5 & Lo adati lohunggia & With the customs of the country \\
18 & Wawu maa toduwolo & And will be welcome \\
56 & Wawu maa pohutuwolo & And it will be implemented \\
72 & Wawu maa popohuliya & And it will be implemented \\
89 & Wawu polengge lomayi & And go here \\
31 & Wawu maa popohuliya & And it will be implemented \\
182 & Wawu maa popohulo'olo & And will be seated \\
186 & Wawu tuwoto lomayi & And come here \\
5 & Wawu maa popohuliya & And it will be implemented \\
55 & Wawu maa pohutuwolo & And it will be implemented
\end{tabular}




$\begin{array}{cl}87 & \text { Wawu polengge lomayi } \\ 60 & \text { Molonggumo to ladiya } \\ 71 & \text { Luwalayi to ladiya } \\ 168 & \text { Malo mayi to ladiya }\end{array}$

$87 \quad$ Wawu polengge lomayi
And go here

The order in the palace

Get out of the palace

It has now arrived at the palace

\subsubsection{Repetition formula based on word repetition}

Speakers of the oral tradition have the freedom to choose and place formulas on the composition of the story at the time of the performance. The technique of the formula was developed to serve himself as an expert or artist (Lord, 1976: 54). The speaker tries to remember the phrases he or she heard from other speakers and who have been used many times in telling a story. They use memories (remembering) as we unconsciously use expressions in ordinary conversation rather than memorization (Lord, 1976: 55-56). Furthermore, Lord (1976: 34) states that every traditional poet presents his story by recreating spontaneously and using a number of available and ready-to-use language elements (words, compounds, phrases). The supply of such formulas is called stock-in-trade. Here is a pattern of repetition of words in tuja'i molo' opu.

(94) Pange wali pange Be empty and be empty

(95) Pange oduta'a Be empty to stirrup

(96) Pange otihula Be empty for standing place

(116) Ode timo ipitalo Like a portable luggage

(117) Ode tumula popalo Like a filled bamboo

(118) Ode pini buo'alo Like a washed cotton

(119) Ode hulawa putalo Like pure gold

Tabel 3. Word repetition

\begin{tabular}{cll}
\hline Lines & Gorontalo Version & Translation \\
\hline 1 & Wombu pulu hunggia & Grandson nobility of the country \\
8 & Wombu malo pudu'olo & Grandson will be crowned \\
50 & Wombu hulawa gumala & Grandson nobility true \\
54 & Wombu banda ilata & Grandson the best son \\
84 & Wombu payu bulayi & Grandson noble nobles \\
88 & Wombu maa toduwolo & Grandson will be welcome \\
100 & Wombu tupalo lomayi & Grandson come here \\
110 & Wombu tupalo lomayi & Grandson come here \\
180 & Wombu tuwoto lomayi & Grandson come here \\
181 & Wombu li Tongohula & Grandson of Tolangohula \\
4 & Malo to dula botiya & Today \\
113 & Malo liyatuwa & Unified and integrated \\
168 & Malo mayi to ladiya & It has now arrived at the palace \\
189 & Malo payu humalo & It has been set in the custom \\
\hline
\end{tabular}

\subsubsection{Repetition formula of the name of the character}

In addition to repeating the word at the beginning and end of the line in the stanza, the tuja'i molo'opu text also has a formula for repeating the name of the character. The figures in the text of this tuja'i Molo'opu are only two. The first or ami 'us', is the tuja'i or traditional leaders representing the Gorontalo people, and the second is the second person in the text, is the person 
being crowned. In the tuja'i molo'opu texts, this crowned person is usually called wombu 'grandson'. Other figures in this text such as tiyombu, starch, mbu'i and rasulu are just as accompanists. Here is a repetition of the name of the character in the tuja'i Molo'opu text.

The word wombu 'grandson' is a word commonly used in tuja'i to greet the envoy person, whether tuja'i marriage, tuja'i cemetery, tuja'l giving the traditional title or tuja'i acceptance. This word wombu is a tribute and appreciation to the man who did the tuja'i. This word wombu has 14 times using this word. This word seems to dominate in tuja'i. This word is usually at the beginning of the line.

Furthermore, the word ami 'us', here the customary leaders introduce themselves. This word is usually at the beginning of the line. Repeating this word 3 times. As a person representing the community, this adat figure considers or declares himself as the tiilo-tiyamo 'parent', or grandpa 'tiyombu'. Thus, giving adat leaders' advice to this beloved man is considered the advice of a grandfather to his grandson.

Here is the word' son '. This word is also regarded as a tribute to the man who did tuja'i. This word includes the word archaic or is no longer used in the daily narrative. Besides the word mbu' $i$ 'madamme' or maybe a word that approximates its meaning is 'puan' or lady. This word is used for a respected woman or a girl, on the use of this word repeated twice. So the words wombu 'grandson', the word ami 'us', 'son' starch, and mbu'i 'madamme' are schematic compositions on the opening element.

Furthermore, the word olongia 'king', although now Gorontalo area is no longer a royal form, this word is still used as penggan said leader or people in power. Then the word rasulu 'rasul' this word belongs to the religious element. The purpose of the use of this word of the apostle in order to run the government, the leader can follow the leadership of the Prophet Muhammad.

Other words as a figure in the tuja'i Molo'opu texts are baate 'custom figures'. This word only repeats twice. Furthermore, the word bandla 'son', this word as a substitute for wombu 'grandson'. This word appears only once.

\subsubsection{The repeat place name formula}

Although tuja' $i$ is only a monologue of the adat figure to the sought-after person, and the tuja'i Molo'opu texts are definite texts but no similar tuja'i texts. This tuja'i molo'opu text contains the name of the place where the repetition becomes a formula in composing tuja'i. The names of the places are like hunggia, madala, ladiya / yiladiya, lipu and upstream. The word hunggia 'land' was once said to be a small kingdom. This word includes the word archaic and is commonly used in tuja'i. Repetition 8 times. The name of this place dominates the name of the place in tuja'i.

Furthermore, the word madala 'country' is similar to the word hunggia (used to call the small kingdom). Repetition of this word 4 times.The word to ladiya, yiladiya 'palace', because the palace is no longer there, so until now this word is used for the home of the new leader's office. This word repeats 3 times. The word lipu/ulipu 'land', now this word is used for village or village. This word repeats 7 times.

The word hunggia 'country', the word madala 'country', to ladiya/yiladiya 'palace', and the word lipu/ulipu 'land' is a schematic composition of the opening element, the steering element, and on almost all elements present in the tuja'i Molo'opu.

\subsection{Formula Tuja'i Molo'opu based on the repetition of suffix word}

According to Lord (1981: 30), a formula is a group of words that are regularly exploited under the same dimensional conditions to express one essential idea (subject). Formulas can be phrases, clauses, and rows. There are rows or half rows that can be entered in formulated rows as arranged according to the system or pattern of the formula (Tuloli, 1990: 143). On these lines, there is at least one same line (Lord, 1981: 47). To further clarify the concept of the formula, Tuloli refers to the concept of Niles that emphasizes the formulaic system as a row group that follows the same rhythm and syntactic patterns and has at least one common principal semantic element (Tuloli 1990: 143 ).

In the tradition of tuja'i molo'opu, the concept of the formula is divided into several types. Formula tuja'i molo'opu tradition uses reps based on word or syllable. This repetition or repetition becomes important, as it will give space for the variation of the tone that exists in the tuja'i molo'opu tradition. Based on existing data, the oral tradition of tuja'i molo'opu has some form of repetition of words or syllables that can be categorized as one of the formulas in the tuja'i tradition of Molo'opu, i.e., repetition of syllables at the end of the line in each verse, the repetition of such syllables olo/alo, ulu/uru, iya/ia, ale, ula, ata and so on almost every stanza in the tuja'i molo'opu tradition. The sound equation at the end of this line is also called rhyme. Rhyme on tuja'i, especially at the end of the line, marking stanzas, episodes, or episodes. The rhyming element, which is at the end of this line, has a function to create the beauty of sound in the listener. The listener is not solely interested in the content and advice of tuja'i, but also the beauty that rhyme creates in tuja'i.

The repetition of syllables/word endings that are almost present in every line on the tuja'i molo'opu is categorized as a kind of indirect necessity before entering the text that exists in each stanza. This can be seen in the tuja'i molo'opu tradition text as follows. 
Table 4. Suffix iya/ia

\begin{tabular}{|c|c|c|}
\hline Lines & Suffix iya/ia & Translation \\
\hline 1 & Wombu pulu lo hunggia & Grandson nobility of the country \\
\hline 2 & Lo lipu duluwo botiya & In these two countries \\
\hline 3 & Lo'u limo lo hunggia & Which occupies the five countries \\
\hline 4 & Malo to dula botiya & Today \\
\hline 5 & Tombuluwa tadidiya & Greeted with admirable greatness \\
\hline 6 & Wawu maa popohuliya & And it will be celebrated \\
\hline 7 & Lo adati lo hunggia & With the customs of the country \\
\hline 59 & Hulalata lo hunggia & The customary provisions of the country \\
\hline 60 & Molunggumo to ladiya & Domestic order \\
\hline 61 & Adati lo hunggia & Provisions of local customs \\
\hline 62 & Dila hikati-katiya & Not by dosage \\
\hline 71 & Luwalayi to ladiya & Get out of the palace \\
\hline 72 & Wawu maa popo huliya & To be celebrated \\
\hline 73 & Lo adati hunggia & With the ancestral customs of the country \\
\hline 74 & To'U wito to utiya & It's over there and it's here \\
\hline 75 & Eyaaaaanggu......... & My Lord ........... \\
\hline 170 & Wombu pulu hunggia & Cucunda son of the land \\
\hline 171 & To lipu duluwo tiya & In these two countries \\
\hline 172 & To'u limo lo hunggia & Which occupies five countries \\
\hline 173 & Malo todula botiya & Today \\
\hline 174 & Timbuluwo botiya & Greeted and honored \\
\hline 175 & Lo'uwito lo utiya & About it and this \\
\hline 176 & Layi'ayi deladiya & Please go to the palace \\
\hline 177 & Bilulo'a maa sadiya & Traditional guarantees are available \\
\hline 178 & To wombu pulu mulia & Prepared for grandson noble \\
\hline 179 & Eyaaaanggu...... & My lord ... \\
\hline
\end{tabular}

Tabel 5. Suffix olo/alo

\begin{tabular}{cll}
\hline Lines & Suffix olo/alo & Translation \\
\hline 8 & Wombu malo pudu'olo & Grandson will be picked up \\
9 & Tombuluwa wunduwolo & Widely and upheld \\
10 & Wawu maa toduwolo & And will be welcome \\
11 & Timihu lumune'olo & Stand up and move on \\
12 & Eyaaanggu......... & My Lord .......... \\
54 & Wombu maa toduwolo & Grandson will be picked up \\
55 & Tombuluwo wundluwolo & Celebrated and glorified
\end{tabular}




$\begin{array}{ll}56 & \text { Wawu maa pohutuwolo } \\ 57 & \text { Timihu lumune'olo } \\ 58 & \text { Eyaaaaanggu........ } \\ 76 & \text { Wombu maa popoluwalolo } \\ 77 & \text { Mondlo yiladiya mulolo } \\ 78 & \text { Wawu maa toduwolo } \\ 79 & \text { Molaahu moluhutolo } \\ 80 & \text { Eyaaaaanggu......... } \\ 114 & \text { Lotutayi lopopalo } \\ 115 & \text { Dilohe yindlalo } \\ 116 & \text { Ode timo ipitalo } \\ 117 & \text { Ode tamula popalo } \\ 118 & \text { Ode pini bubo'alo } \\ 119 & \text { Ode hulawa putalo } \\ 120 & \text { Eyaaanggu......... }\end{array}$

And will be implemented

Please stand up and go

My lord.........

Grandson is welcome out

From the ancient palace (private house)

And will be welcome

To down the traditional stairs.

My lord...........

Without worry and doubt

Worry and fear

Like a carry-on

Like a cleaned bamboo

Like a washed cotton

Like pure gold

My lord..........

Tabel 6. Suffix Ulu/uru

\begin{tabular}{|c|c|c|}
\hline Lines & Suffix Ulu/uru & Translation \\
\hline 34 & Pati hulawa lo wulu & The true noble son of \\
\hline 35 & Didi lo'u londlo hulu & Which comes from upstream \\
\hline 36 & Taa pobadari to rasulu & The proponent of the sunnah of the apostle \\
\hline 37 & Ulipu motombulu & Customary stakeholders make a speech \\
\hline 38 & Yilodu'a lo syukuru & Pray and be grateful \\
\hline 39 & Olayidu umuru & Hopefully, live longer \\
\hline 40 & Lumene'o tumundulu & Rising in everything \\
\hline 41 & Toduwolo motihuloo to katulu & Seated on the mattress \\
\hline 42 & Eyaaaaanggu......... & My Lord......... \\
\hline 143 & Pati hulawa lo wulu & True noble son \\
\hline 144 & Didi lo'u londlo hulu & Which comes from upstream \\
\hline 145 & Tombuluwa to madala & Honored by customary stakeholders \\
\hline 146 & Taa pobadari to rasulu & The proponent of the sunnah of the apostle \\
\hline 147 & Ulipu motomb $\underline{u l u}$ & Adat stakeholders carry out \\
\hline 148 & Olayidu umuru & Hopefully, live longer \\
\hline 149 & Lumene'o tumundulu & Rising in everything \\
\hline 150 & Eyaaaaanggu.......... & My Lord........ \\
\hline
\end{tabular}


Tabel 7. Suffix ale

\begin{tabular}{cll}
\hline Lines & \multicolumn{1}{c}{ Suffix ale } & Translation \\
\hline 160 & Lengge ahi motiyale & Going on \\
161 & Taluhi mbu'l Bungale & Following Mbu'i Bungale's mother \\
162 & Wali binde lolale & The true noble race \\
163 & Talude'o timbuwale & With no exception \\
164 & Lipu duwolu lumale & Both countries glorify \\
165 & Lumonggia limondlale & Carefully walk \\
166 & Lumondlale lumonggia & Walk carefully \\
167 & Tolipu duluwo tiya & In these two countries \\
168 & Malo mayi to ladiya & It has now arrived at the palace \\
169 & Eyaaaaanggu........ & My lord .......... \\
\hline
\end{tabular}

Tabel 8. Suffix ula

\begin{tabular}{cll}
\hline Lines & \multicolumn{1}{c}{ Suffixula } & \multicolumn{1}{c}{ Translation } \\
\hline 182 & Tuwotayi to dutula & \\
183 & Panggeta lalande bula & Enter through this path \\
184 & Mbu'l wawu huhundula & The curtain had been uncovered \\
185 & Wali limato lo dula & Mother with escorts sultan of Matolodula \\
186 & Wombu li Tolangoh $\underline{\text { ula }}$ & Grandson of Mbu'i Tolangohula \\
187 & Hulawa de tilih $\underline{\underline{u} \text { la }}$ & It's like big gold \\
188 & Eyaaaaanggu..... & My lord ...... \\
\hline
\end{tabular}

Tabel 9. Sufix ala

\begin{tabular}{cll}
\hline Lines & \multicolumn{1}{c}{ Sufix ala } & \multicolumn{1}{c}{ Translation } \\
\hline 7 & Wombu hulawa gumala & Grandson true son \\
8 & Tombuluwa to madala & with the customs of greatness \\
9 & Poli poo ambuwala & Already with agreement \\
10 & Lo udula'a kimala & By customary stakeholders \\
50 & Wombu hulawa gumala & Grandson true son \\
51 & Tombuluwa to madala & with the customs of greatness \\
52 & Poli poo ambuwala & Already with agreement \\
53 & Lo udula'a kimala & By customary stakeholders \\
\hline
\end{tabular}


Table 10. Sufix Ata

\begin{tabular}{cll}
\hline Lines & \multicolumn{1}{c}{ Sufix Ata } & \multicolumn{1}{c}{ Translation } \\
\hline 81 & Hiambuwa hipadata & All the people gathered \\
82 & Molimengo ilomata & Expect grace \\
83 & Wombu bandla ilata & Grandson becomes leader \\
84 & Donggo eya ta kawasa & God is decisive \\
85 & To olandlo potuhata & On my master's instructions \\
86 & Eyaaaaanggu......... & My Lord .......... \\
\hline
\end{tabular}

From a table of syllable repetitions at the end of this line, the prominent feature in this tuja'i is the use of the most " 0 " sounds, as in the "po", "alo", "mo/ngo" suffixes. This is in accordance with what is stated by Tuloli (1991: 199) Gorontalo language is a vocalist language so that every syllable is covered with vowels. Of the five main vowels in Gorontalo, it turns out that " $O$ " is more dominant in the formation of the final rhyme. Other sounds are used with low frequencies. In addition to the " 0 " sound, the sound "a" includes those used as the final rhyme in tuja'i, for example: "iya / ia", "la", "ata", "ala", "uwa", and so on. So the sound element used to build rhymes in tuja'i molo'opu can not be separated from the Gorontalo language phonetic system.

\section{Conclusion}

This study aims to find the characteristics of the formula as the identity of Gorontalo oral literature, especially Tuja'i. Formulas in Tuja'i can reveal how much vocabulary the speaking community has, and how they express it. Tuja'i Molo'opu is oral literature delivered at the Molo'opu ceremony or the reception ceremony of officials who rule in Gorontalo district. This ceremony is a relic of the past that the system of appointment or acceptance of its leader is still relevant to this modern era. Molo'opu traditional ceremony is inseparable from the performance aspect as an important part of oral tradition. Every movement on the performance of the Molo'opu ceremony, accompanied by oral literature tuja'i. The tuja'i Molo'opu text at each performance of this ceremony follows or mimics some of the earlier texts, but the tuja'i can develop or reconstruct the tuja' $i$ text with its own formula. Thus there is no similar tuja'i text from any performance of the ceremony. Composing this formula is done by replacing, combining, forming models, and adding new words or phrases to the formula according to needs spontaneously. This research shows that formula tuja'i Molo'opu has the formula (1) repetition of lines, (2) repetition of word group/phrase, (3) formula of word repetition, (4) formula varied repetition, (5) parallelism. This study is hoped to be a complement of literature about Gorontalo oral literature. However, many things cannot be studied in this research, such as the dominant consonant sounds and other aspects of oral poetry. Therefore, it is hoped that further studies could be conducted using other theories and other aspects of oral literature.

Funding: This research received no external funding.

Acknowledgments: The author would like to extend her great gratitude to all parties involved in this research.

Conflicts of Interest: The authors declare no conflict of interest.

\section{References}

[1] Ministry of Education and Tourism. (2005). Upacara adat Propinsi Gorontalo [Gorontalo Province traditional ceremony]. Depbudpar.

[2] Finnegan, R. (1979). Oral poetry: It's nature significance and social context. Cambridge University Press.

[3] Finnegan, R. (2012). Oral tradition and the verbal arts. Allan Chapman and Hall

[4] Keraf, G. (1996). Diksi dan gaya bahasa [Diction and language style]. Gramedia.

[5] Lord, A. B. (1976). The singer of tales. Atheneum.

[6] Ong, W. J. (1989). Orality and literacy: The technologizing of the word. Methuen.

[7] Pemkab Gorontalo. (1985). Empat aspek adat daerah Gorontalo [Four aspects of Gorontalo's local customs]. Pemkab Gorontalo.

[8] Pemkab Gorontalo. (2001). Laporan seminar upacara adat-istiadat Gorontalo [Gorontalo traditional ceremony seminar report]. Pemkab Gorontalo.

[9] Tuloli, N. (1994). Sastra lisan Gorontalo: Aspek budaya daerah yang perlu dilestarikan Gorontalo [Gorontalo oral literature: Aspects of regional culture that need to be preserved Gorontalo]. STKIP Gorontalo. 